\title{
Penguatan peran warga masyarakat dalam mitigasi dan adaptasi menghadapi wabah Covid-19 di Kabupaten Kolaka
}

\author{
Sudarman Rahman ${ }^{1 *}$, Sahidin ${ }^{1}$ \\ 1Program Studi Farmasi, Fakultas Farmasi, Universitas Halu Oleo, Kendari, Indonesia.
}

DOI: https://doi.org/10.29303/indra.v2i1.51

\section{Article Info}

Received : 10-08-2020

Revised : 29-04-2021

Accepted: 29-04-2021

\begin{abstract}
WHO China Country Office reported pneumonia cases in Wuhan, Hubei Province, China. The virus was lately identified as a new strain of corona virus called Severe Acute Respiratory Syndrome Coronavirus-2. The new cases grow massively and became pandemic. Regarding this rapid transmission, there is a need for socialization to strengthen people's awareness and role in mitigation and adaptation against this COVID19 pandemic. The method used was counseling with socialization or lectures and supported interactions in the form of questions and answers by using power points and leaflets/brochures as information media. This community engagement included the activities of the Movement for Healthy Living Society (GERMAS), Clean and Healthy Living Behavior (PHBS), Use of Personal Protective Equipment such as using masks, Use of Antiseptics and Disinfectants, and Planting Family Medicines (TOGA). The implementation of this activity began with socialization to the local community at the village hall, then to the houses of residents to deliver the subject contained in the brochure/leaflet, and last by placing pamphlets in public places to provide information to the community related to the activities that had been done. This socialization is expected to increase public awareness to face against this corona virus disease outbreak.
\end{abstract}

Keywords : Corona Virus, SARS-CoV-2, Socialization

Citation: Sudarman, R \& Sahidin (2021). Penguatan Peran Warga Masyarakat Dalam Mitigasi dan Adaptasi Menghadapi Wabah Covid-19 di Kabupaten Kolaka. INDRA: Jurnal Pengabdian kepada Masyarakat, 2(1), 15-21. doi: https://doi.org/10.29303/indra.v2i1.51

\section{Pendahuluan}

World Health Organization China Country Office melaporkan kasus pneumonia yang tidak diketahui etiologinya di Kota Wuhan, Provinsi Hubei, Cina. Pada tanggal 7 Januari 2020, Cina mengidentifikasi pneumonia tersebut sebagai jenis baru virus corona (coronavirus disease, COVID-19). Pada tanggal 30 Januari 2020, Organisasi Kesehatan Dunia (WHO) telah menetapkan sebagai Kedaruratan Kesehatan Masyarakat Yang Meresahkan Dunia (Kemenkes RI, 2020). Penambahan jumlah kasus COVID-19 berlangsung cukup cepat dan sudah terjadi penyebaran antar negara. Sebanyak 210 negara telah melaporkan kasus infeksi virus corona ini, hal ini membuktikan bahwa penyebaran virus corona terjadi dalam waktu singkat (Ortega dkk., 2020).

Coronavirus Disease 2019 (COVID-19) adalah virus baru penyebab penyakit pernafasan, tanda dan gejala umum infeksi COVID-19 antara lain gejala gangguan pernapasan akut seperti demam, batuk dan sesak napas. Masa inkubasi rata-rata 5-6 hari dengan masa inkubasi terpanjang 14 hari. Pada kasus COVID19 yang berat dapat menyebabkan pneumonia, sindrom pernapasan akut, gagal ginjal, dan bahkan 
kematian. Tanda-tanda dan gejala klinis yang dilaporkan pada sebagian besar kasus adalah demam, dengan beberapa kasus mengalami kesulitan bernapas, dan hasil rontgen menunjukkan infiltrat pneumonia luas di kedua paru (Kemenkes RI, 2020). Diketahui virus ini merupakan satu keluarga dengan virus penyebab SARS (Severe Acute Respiratory Syndrome) dan MERS (Middle East Respirator Syndrome). COVID-19 adalah penyakit jenis baru yang belum pernah diidentifikasi sebelumnya pada manusia. Virus penyebab COVID-19 dinamakan Severe Acute Respiratory Syndrome Coronavirus-2 (SARS-CoV-2). (Kemenkes RI, 2020). Penyebaran penyakit ini telah memberikan dampak luas secara sosial dan ekonomi. Masih banyak kontroversi seputar penyakit ini, termasuk dalam aspek diagnosis, tata laksana, hingga pencegahan.

COVID-19 dapat menular dari manusia melalui kontak erat dan droplet. Orang yang paling berisiko tertular penyakit ini adalah orang yang kontak erat dengan pasien COVID-19 termasuk yang merawat pasien COVID-19 (WHO, 2020).

Berdasarkan rekomendasi standar Kementerian Kesehatan Republik Indonesia untuk mencegah penyebaran infeksi virus corona, maka perlu dilakukan kegiatan yang bermanfaat seperti Gerakan Masyarakat Hidup Sehat (GERMAS), menggunakan Alat Pelindung Diri (APD) sederhana seperti masker dan tetap melaksanakan jaga jarak, membaca jenis tanaman obat yang dapat meningkatkan sistem imun serta penggunaan antiseptik dan desinfektan untuk membantu dalam mencegah penyebaran COVID-19.

Germas merupakan gerakan nasional yang diprakarsai oleh Presiden Republik Indonesia yang mengedepankan upaya promotif dan preventif tanpa mengesampingkan upaya penyembuhan dan pemulihan dengan melibatkan seluruh komponen bangsa dalam memasyarkatkan paradigma sehat. Untuk menyukseskan GERMAS, tidak bisa hanya mengandalkan peran sektor kesehatan saja. Peran Kementerian dan Lembaga di sektor lainnya juga turut menentukan, dan ditunjang peran serta seluruh lapisan masyarakat dalam mempraktekkan pola hidup sehat, derajat kesehatan dipengaruhi oleh 4 faktor yaitu faktor lingkungan, faktor perilaku, faktor keturunan dan faktor pelayanan kesehatan. Salah satu faktor yaitu faktor perilaku yang sangat berpengaruh dalam kesehatan seseorang, terutama dalam penerapan PHBS (Perilaku Hidup Bersih dan Sehat) baik di lingkungan pribadi, keluarga, maupun masyarakat (Andriansyah \& Desi, 2013).

Perilaku hidup bersih dan sehat (PHBS) adalah semua perilaku kesehatan yang dilakukan karena kesadaran pribadi sebagai hasil pembelajaran sehingga keluarga dan seluruh anggotanya mampu menolong diri sendiri pada bidang kesehatan serta memiliki peran aktif dalam aktivitas masyarakat (Permenkes RI, 2011).

Masker adalah perlindungan pernafasan yang digunakan sebagai metode untuk melindungi individu dari menghirup zat-zat bahaya atau kontaminan yang berada di udara, perlindungan pernafasan atau masker tidak dimaksudkan untuk menggantikan metode pilihan yang dapat menghilangkan penyakit, tetapi digunakan untuk melindungi secara memadai pemakainya (Cohen \& Birdner, 2012). Menggunakan masker saat beraktivitas di luar rumah dapat memutus penyebaran Covid-19 dengan mengikuti saran World Health Organization (WHO) untuk mencegah penyebaran Covid-19 (WHO, 2020).

Selain menggunakan masker untuk mencegah penyebaran virus corona, penggunaan desinfektan danantiseptik. Desinfektan dan antiseptik yang biasa digunakan pada umumnya berasal dari bahan kimia sintetis berupa bahan kimia buatan. Bahan kimia sintetis memiliki kelebihan yaitu dapat mereduksi bakteri dengan cepat, namun juga memiliki kekurangan yaitu dapat menyisakan residu dan sulit untuk terurai, maka dari itu penggunaan bahan kimia sintetis perlu dikurangi dan digantikan dengan bahan alami yaitu bersumber dari alam (Widyastari dkk., 2015).

Berdasarkan latar belakang tersebut, perlu dilakukan sosialisasi penguatan peran warga masyarakat dalam mitigasi dan adaptasi menghadapi wabah Covid-19, sehingga dengan adanya sosialisasi kegiatan ini dapat membantu masyarakat dalam menerapkan gerakan masyarakat perilaku hidup bersih dan sehat, memakai masker dan jaga jarak, serta menggunakan antiseptik dan desinfektan untuk mencegah penularan covid-19.

\section{Metode}

Pelaksanaan kegiatan pengabdian kepada masyarakat merupakan bagian dari KKN TEMATIK mahasiswa dari berbagai Fakultas Universitas Halu Oleo sebanyak 26 mahasiswa serta masyarakat di wilayah Desa Sumber Rejeki, Kecamatan Watubangga, Kabupaten Kolaka. Metode yang digunakan yaitu penyuluhan dengan sosialisasi didukung interaksi yang dapat berupa tanya-jawab serta mengajarkan langsung pembuatan masker, antiseptik dan desinfektan dari bahan alam kepada warga setempat.

\section{Hasil dan Pembahasan}

Penularan COVID-19 dapat dengan mudah tersebar yaitu ketika terinfeksi dari batuk dan bersin penderita, menyentuh wajah setelah kontak dengan cairan dari mulut penderita, atau menyentuh barang 
yang telah ada cairan dari mulut penderita. Kasus yang lebih parah dari infeksi virus ini yaitu dapat menyebabkan pneumonia, sindrom pernapasan akut, gagal ginjal hingga kematian (Burhan dkk., 2020). Oleh karena itu, maka dilakukan beberapa langkah untuk mencegah penyebaran COVID-19 melalui kegiatan KKN TEMATIK dapat membantu masyarakat dalam menerapkan gerakan masyarakat hidup sehat (GERMAS), Perilaku Hidup Bersih dan Sehat (PHBS), Menggunakan Masker dan Jaga Jarak (MJJ), serta penggunaan antiseptik dan desinfektan dari bahan alam. Diharapkan dengan kegiatan tersebut dapat menjadi penguat warga masyarakat dalam menghadapi COVID-19 dan mencegah rantai penyebaran virus corona.

\section{A. Gerakan Masyarakat (GERMAS)}

Program KKN Tematik dari Tim GERMAS, dilaksanakan dengan mengadakan sosialisasi gizi seimbang untuk meningkatkan imunitas tubuh, sosialisasi mengenai pentingnya olahraga, dan sosialisasi mengenai bahaya merokok terkait COVID-19 di desa Sumber Rejeki Kecamatan Watubangga Kabupaten Kolaka yang bertujuan untuk menggerakkan masyarakat dalam melakukan pola hidup sehat kepada seluruh elemen masyarakat.

Gerakan masyarakat hidup sehat (GERMAS) merupakan gerakan nasional yang diprakarsai oleh presiden RI yang menghendakan upaya promotif dan prepentif dengan melibatkan seluruh komponen bangsa dan memasyarakatkan paradigm sehat.

Sosialisasi yang dilakukan menggunakan 3 cara, yang pertama dengan mengumpulkan massa, sosialisasi yang kedua dengan cara dari rumah ke rumah (door to door) dan sosialisasi yang ketiga dengan cara membagikan pamflet maupun brosur serta penempelan brosur di rumah warga.

Kegiatan pertama yaitu sosialisasi dengan mengumpulkan warga sebanyak 15 orang beserta dengan Kepala Desa, Sekretaris Desa, maupun aparat desa yang bertempat di Balai Desa Sumber Rejeki.Kegiatan sosialisasi yang dilakukan berjalan baik dan lancar. Masyarakat sangat mengapresiasi timKKN Tematik Kabupaten Kolaka menyelenggarakan sosialisasi di desa mereka. Kegiatan ini juga dilakukan sesuai dengan protokol kesehatan.

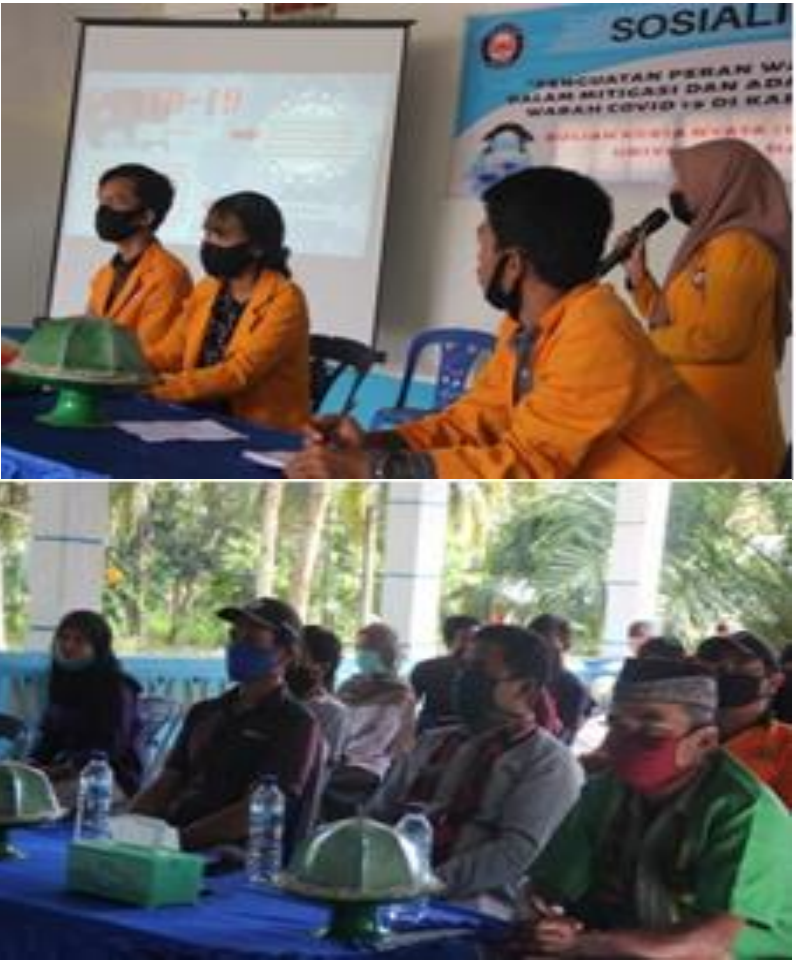

Gambar 1. Sosialisasi oleh tim GERMAS

Kegiatan kedua yaitu sosialisasi dengan cara door to door. Sosialisasi ini dilakukan dikarenakan tidak semua masyarakat di Desa Sumber Rejeki mengetahui sosialisasi yang telah dilakukan oleh tim KKN di Balai Desa, maka kami melakukan sosialisasi dengan cara door to door agar semua masyarakat dapat menjaga kesehatan dengan makan makanan yang bergisi, selalu berolahraga yang cukup dan rutin serta berhenti merokok dalam menghadapi COVID-19.

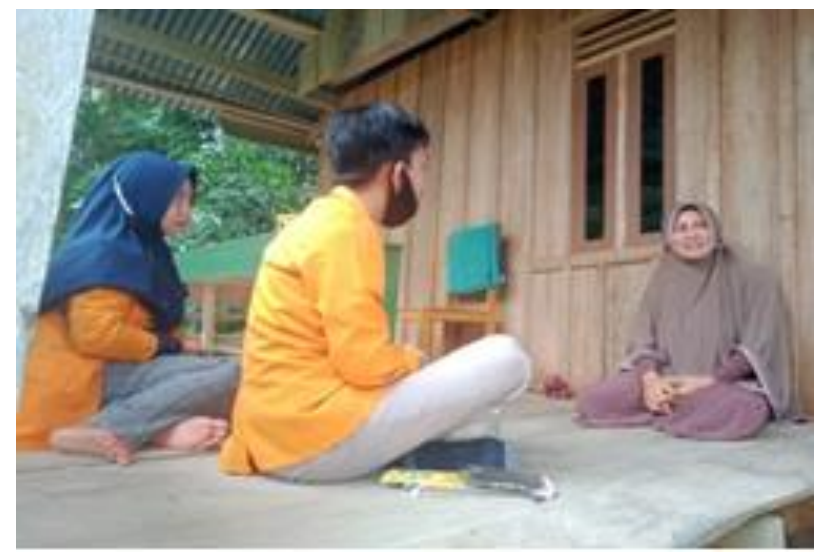

Gambar 2. Sosialisasi di Rumah Warga

Kegiatan ketiga yaitu sosialisasi dengan menggunakan media pamflet, brosur maupun poster. Media pamflet, brosur maupun poster juga sangat efektif dan dapat menumbuhkan kegemaran membaca masyarakat. 


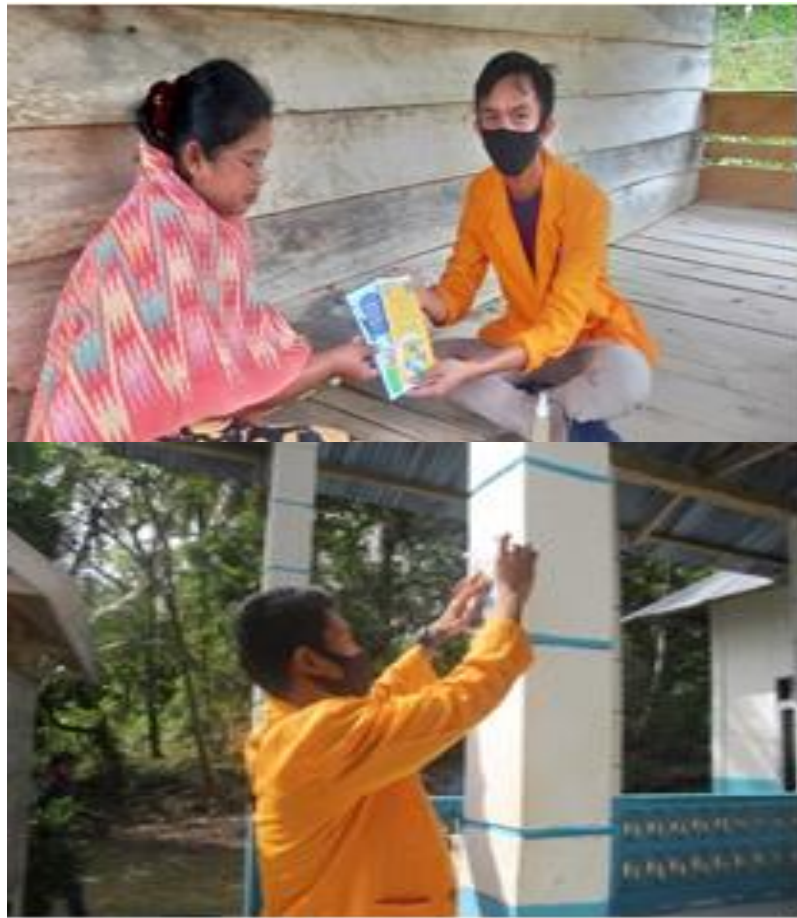

Gambar 3. Pembagian pamflet, brosur dan penempelan poster

\section{B. Perilaku Hidup Bersih dan Sehat (PHBS)}

Salah satu upaya menuju kearah perilaku sehat dengan melalui satu program yang dikenal dengan program perilaku hidup bersih dan sehat (PHBS) yang dilaksanakan secara sistematis dan terkordinir. Sebelum melakukan kegiatan KKN tematik, tentang upaya Penguatan Peran Warga Masyarakat Dalam Mitigasi dan Adaptasi Menghadapi Covid-19 di Kabupaten Kolaka, kami meminta persetujuan kepada kepala desa Sumber Rejeki untuk melakukan rangkaian kegiatan sosialisasi kepada masyarakat setempat.

Perilaku hidup bersih dan sehat (PHBS) merupakan bentuk perwujudan untuk memberikan pengalaman belajar atau menciptakan suatu kondisi yang kondusif bagi perorangan, keluarga, kelompok dan masyarakat untuk meningkatkan pengetahuan, sikap dan perilaku agar dapat menerapkan cara-cara hidup sehat dalam rangka menjaga, memelihara, dan meningkatkan kesehatan. perilaku hidup bersih dan sehat (PHBS) selama masa pandemik adalah program khusus dari dari pemerintah Indonesia. tujuannya adalah meningkatkan kualitas kesehatan masyarakat Indonesia secara keseluruhan. Diharapkan setiap individu menjadi sadar atas kesehatan dan mampu menjalankan perilaku bersih dan sehat dalam kehidupan sehari-hari selama masa pandemi COVID19 yang sudah menyebar didunia, termasuk di Indonesia (Gani, dkk., 2015).

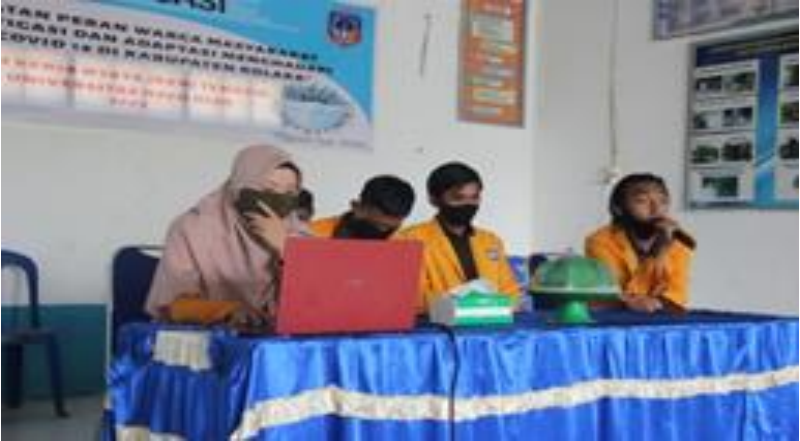

Gambar 4. Sosialisasi kepada masyarakat mengenai PHBS

Materi yang disajikan adalah materi penyuluhan tentang cuci tangan yang baik dan benar dengan sabun dan air mengalir. PHBS mendukung kebersihan pribadi dan menghindari penularan berbagai penyakit melalui tangan yang terkontaminasi kuman/bakteri/virus. Pemberian materi ini diharapkan memberikan pemahaman kepada warga tentang pentingnya mencuci tangan menggunakan sabun dengan airmengalir sebelum dan sesudah melakukan aktivitas Kegiatan tersebut dapat berjalan dengan baik dan lancar. Warga sangat antusias dan dapat bekerja sama dengan baik, serta dapat mempraktikkan mencuci tangan dengan sabun menggunakan air mengalir.

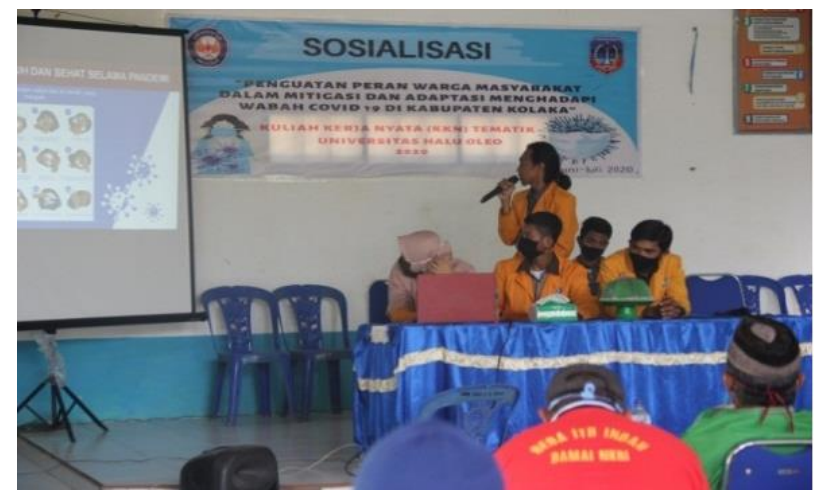

Gambar 5. Sosialisasi cara cuci tangan yang baik dan benar

\section{Masker dan Jaga Jarak (MJJ)}

Menggunakan masker saat beraktivitas di luar rumah dapat memutus penyebaran Covid-19 dengan mengikuti saran World Healt Organization (WHO) untuk mencegah penyebaran Covid-19.

Ketika pandemi virus corona Covid-19 melanda seperti sekarang ini, kebutuhan akan masker jadi semakin meningkat tim KKN TEMATIK Kabupaten Kolaka membuat masker sendiri yang kemudian dibagikan ke masyarakat setempat. Jenis-jenis masker yaitu masker kain (untuk orang sehat) masker kain dapat digunakan oleh masyarakat yang sehat di tempat umum dan berinteraksi dengan orang lain dengan tetap menjaga jarak minimal 1-3 meter. Cara memakai 
masker yang baik dan benar sebelum menggunakan masker, cuci tangan dengan sabun atau hand sanitizer berbasis alkohol.Pasang masker menutupi mulut dan hidung, pastikan tidak ada selah antara wajah dan masker, tekan bagian atas masker agar mengikuti bentuk hidung dan tarik ke belakang di bagian bawah dagu.Lepaskan masker yang telah digunakan dengan memegang tali (jangan menyentuh bagian depan masker).

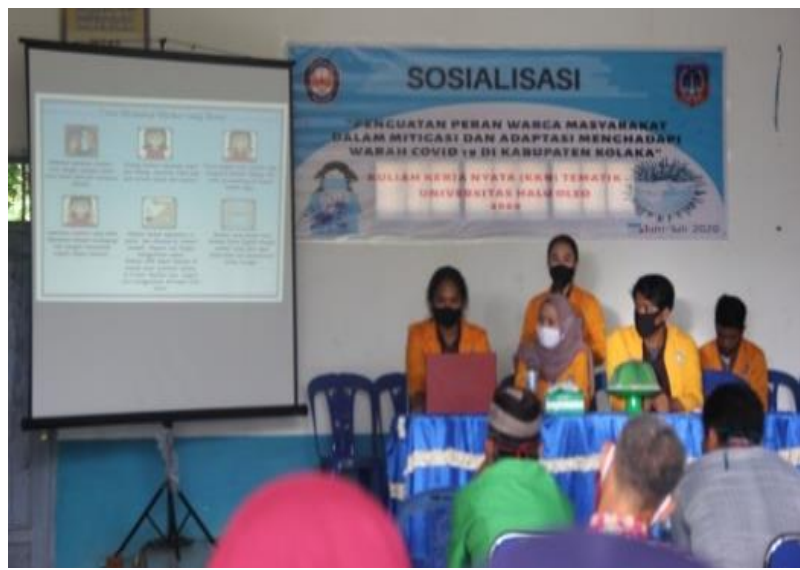

Gambar 6. Sosialisasi cara memakai masker

Pentingnya menggunakan masker di masa pandemik ini sangat dianjurkan oleh Organisasi Kesehatan Dunia (WHO), berikut tingkat resiko penularan penyakit COVID-19:

1. Jika seseorang yang sakit tidak menggunakan masker dan bertemu seseorang yang sehat tanpa masker maka resiko penelurannya yaitu $90 \%$.

2. Jika seseorang yang sakit menggunakan masker dan bertemu seseorang yang sehat tanpa masker maka resiko penularannya yaitu $70 \%$.

3. Jika seseorang yang sehat menggunakan masker dan bertemu dengan seseorang yang sakit tanpa menggunakan masker maka resiko penularannya yaitu $5 \%$.

4. Jika seseorang yang sehat menggunakan masker dan bertemu seseorang yang sakit memakai masker maka resiko penulrannya yaitu sebesar 1,5\%. (WHO, 2020).

\section{Antiseptik dan Desinfektan}

Salah satu program KKN tematik yang dilaksanakan yaitu sosialisasi tentang antiseptik dan desinfektan serta menampilkan video cara pembuatan antiseptik dan desinfektan dari bahan alami kemudian membuat pamflet yang akan ditempelkan di tempat umum, dan membagikan brosur dan leaflet ke rumahrumah warga. Perbedaan antiseptik dan desinfektan penting diketahui untuk menghindari terjadinya salah penggunaan antara antiseptik dan desinfektan oleh masyarakat. Antiseptik digunakan menghilangkan mikroorganisme pada jaringan hidup (kulit) sedangkan desinfektan digunakan untuk menghilangkan mikroorganisme pada benda mati (Sari \& Pramardika 2020).

Pembuatan antiseptik dan desinfektan oleh Tim KKN TEMATIK Kabupaten Kolaka yang dibuat dari bahan alami, berdasarkan jurnal penelitian yang membuktikan bahwa bahan alami tersebut memiliki kemampuan sebagai antimikroba seperti daun sirih, jeruk nipis, daun jeruk purut dan sereh.

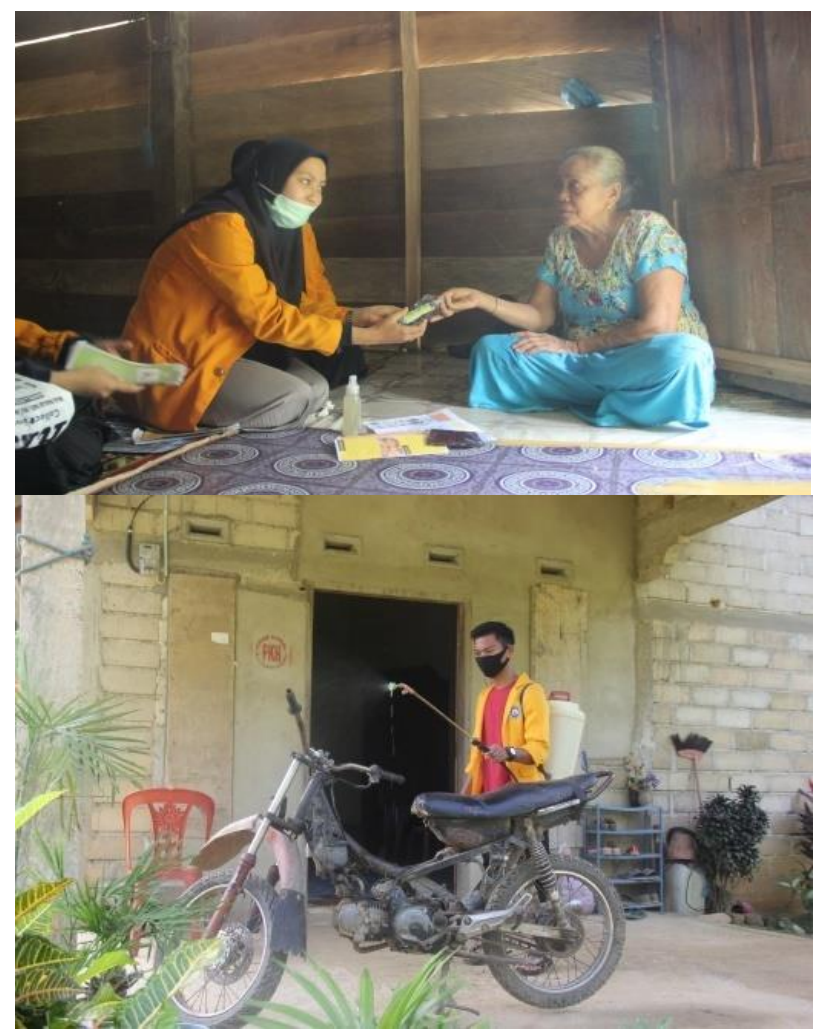

Gambar 7. Pembagian antiseptik dan Penyemprotan desinfektan

\section{E. Tanaman Obat Keluarga (TOGA)}

Kegiatan Tanaman Obat Keluarga (TOGA) oleh Tim KKN Kabupaten Kolaka di Desa Sumber Rejeki diawali dengan mensosialisasikan terkait dengan TOGA, kemudian membagikan brosur/leaflet kepada warga setempat, hal ini sangat penting mengingat banyak masyarakat yang belum mengenal tanaman obat keluarga atau disebut apotek hidup, membuat landscapeuntuk penanaman TOGA selanjutnya melakukan penanaman Tanaman Obat Keluarga (TOGA).

Desain landscape TOGA yang dibuat Tim KKN Kabupaten Kolaka yaitu Arsitektur Lanskap, dimana definisi dari arsitektur lanskap adalah ilmu Arsitektur yang fokus padapengaturan ruang dan massa di alam terbuka, dengan mengkombinasikan elemen-elemen penataan lanskap, bukan sekedar bangunan. Secara bahasa, arsitektur lanskap adalah bidangilmu (science) dan seni (art) yang mempelajari lanskap alami ataupun buatan manusia, baik secara horizontal maupun 
vertikal, dengan segenap kegiatannya, agar tercipta karya lingkungan yang secara fungsional berguna dan secara estetika tetap indah.

Konsep Taman Toga (tanaman obat keluarga) atau yang lebih dikenal taman apotek hidup sangat bermanfaat. Pengobatan herbal pun bisa Anda dapatkan dengan mudah di halaman rumah. Taman menjadi pelengkap sebuah desain rumah yang tak bisa disepelekan. Selain menambah estetika, taman juga bisa menjadi lahan untuk menanam tumbuhan apotek hidup yang sangat besar manfaatnya.

Lebih dari 1000 spesies tumbuhan dapat dimanfaatkan sebagai bahan baku obat, oleh karena itu budidaya tanaman obat di Indonesia memiliki potensi yang sangat baik untuk dikembangkan (Nugraha \& Wanda, 2015). Tanaman obat keluarga yang diambil di Desa Sumber Rejeki yaitu jahe, kunyit, temulawak, sereh, dan daun sirih, karena tanaman tersebut sangat mudah ditemukan.Tanaman tersebut memiliki banyak manfaat bagi kesehatan tubuh salah satunya yaitu meningkatkan sistem imun tubuh agar tidak mudah terserang penyakit termasuk COVID-19.

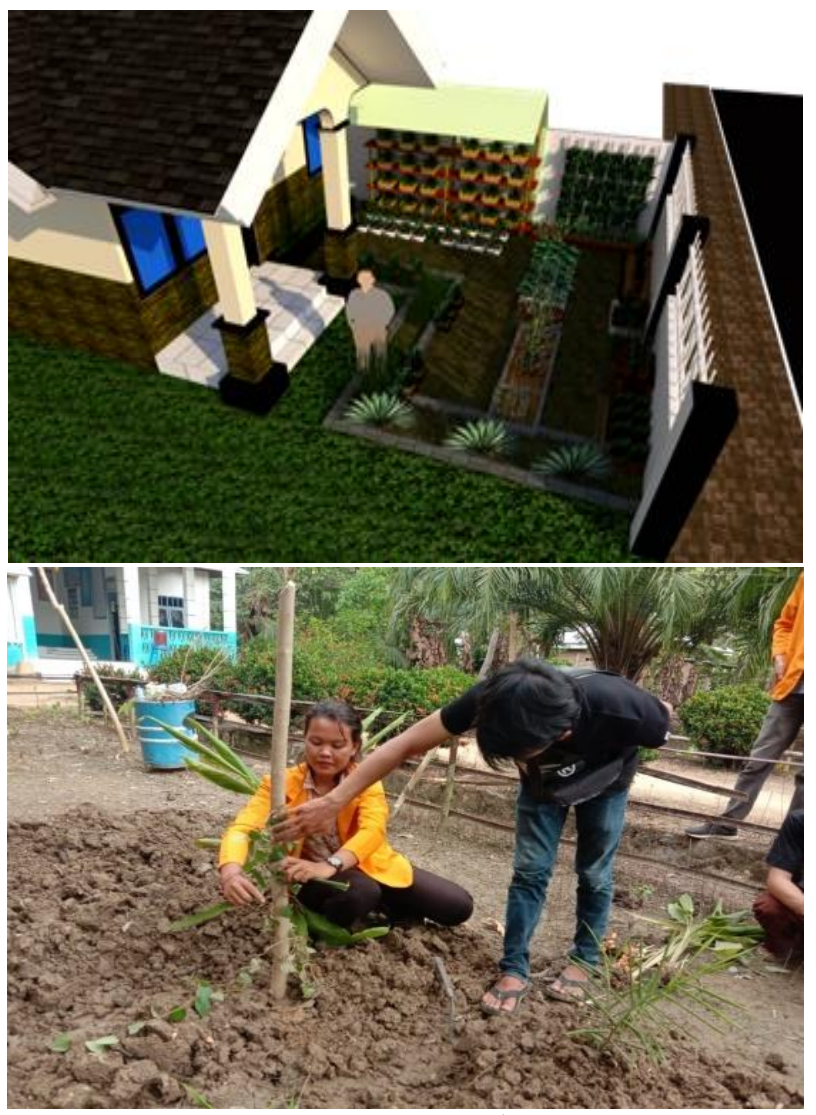

Gambar 8 : Penanaman TOGA dan Lanscape TOGA

\section{Simpulan}

Telah dilaksanakan kegiatan pengabdian kepada masyarakat di Desa Sumber Rejeki Kecamatan Watubangga Kabupaten Kolaka. Kegiatan pengabdian ini berupa sosialisasi berupa materi dan pembagian brosur/leaflet kepada warga setempat yang dilakukan Mahasiswa KKN Tematik Universitas Halu Oleo. Kegiatan ini terlaksana dengan baik karena munculnya kepedulian masyarakat setempat akan pentingnya kesehatan di tengah wabah Covid-19 serta kegiatan ini mendapatkan izin dari Kepala Desa dan aparat desa serta partisipasi dari warga setempat dalam menyukseskan kegiatan ini.

\section{Ucapan TerimaKasih}

Ucapan terima kasih kami ucapkan kepada Kepala Desan dan Aparat Desa serta masyarakat Desa Sumber Rejeki Kecamatan Watubangga Kabupaten Kolaka yang telah membantu kegiatan pegabdian kepada masyarakat.

\section{Daftar Pustaka}

Andriansyah. Y. \& Desi, N. R. 2013, Penyuluhan dan Praktik PHBS (Perilaku Hidup bersih Sehat) dalam Mewujudkan Masyarakat Desa Peduli Sehat. Jurnal Inovasi dan Kewirausahaan.Vol. 2(1).

Burhan, E., Isbaniah, F., Susanto, A.D., Aditama, T.A., Soedarsono, \& Teguh, R.S. (2020). Pneumonia Covid-19 Diagnosis \& Penatalaksanaan di Indonesia. Perhimpunan Dokter Paru Indonesia. Jakarta.

Cohen DE, Jacob SE. Allergic Contact Dermatitis (2012). Dalam: Wolf K, Goldsmith LA,Katz SI, Gilchrestba, Paller AS, Leffel DA,ed.Flitzpatricks Dermatology in General MedicineEdisi Ke-7.USA: The McGraw-Hill Companies, Inc.

Gani, H.A., Istiaji. E., \& Pratiwi, P.E. (2015). Perilaku Hidup Bersih Dan Sehat (PHBS) Pada Tatanan Rumah Tangga Masyarakat (Studi Kualitatif Di Desa Kemiren, Kecamatan Glagah, Kabupaten Banyuwangi. Jurnal IKESM. Vol. 11(1).

Kementerian Kesehatan RI. (2020). Pedoman Pencegahan dan Pengendalian Coronavirus Disease 2019 (COVID-19).Jakarta : Kementerian Kesehatan Republik Indonesia.

Nugraha, S., \& Wanda, R. A. (2015). Pelatihan Penanaman Tanaman Obat Keluarga (TOGA). Jurnal Inovasi dan Kewirausahaan.Vol. 4(1).

Ortega,J.S., Soerrano, M.L., Pujol, F.H., \&Hector, R.R. (2020). Role Of Change in SARS-COV-2 Spike Protein in The Interaction With The Human ACE-2 Receptor An in Silico Analysis.Journal Excli, 19(2), 410-417. 
Peraturan Menteri Kesehatan RI. (2011). Peraturan Menteri Kesehatan Republik Indonesia nomor: 2269/MENKES/PER/XI/2011.Pedomanpembinaan perilaku hidup bersih dan sehat (PHBS). Jakarta : Kementerian Kesehatan Republik Indonesia.

Sari, A.D. \& Pramardika, R. (2020).Penggunaan Antiseptik dan Desinfektan.Vol. 2(2).

WHO. (2020). Controlling Coronavirus Disease (COVID19). Geneva: World Health Organizations.

Widyastari, T., Ellin H., \& Eulis T.M. (2015).Efektivitas Kulit Daun Lidah Buaya sebagai Desinfektan Alami terhadap Daya Hambat dan Penurunan Jumlah Bakteri Total di Ruang Penampungan Susu.Jurnal Unpad. Vol. 4(4). 